\title{
Drinking Water in Northwestern Alaska: Using or Not Using Centralized Water Systems in Two Rural Communities ELIZABETH MARINO, ${ }^{1}$ DAN WHITE, ${ }^{2}$ PETER SCHWEITZER, ${ }^{3}$ MOLLY CHAMBERS ${ }^{2}$ and JOSH WISNIEWSKI ${ }^{3}$
}

\author{
(Received 6 September 2007; accepted in revised form 27 May 2008)
}

\begin{abstract}
Over the last 100 years, there have been major changes in the way Iñupiaq villages in Alaska have procured fresh water for drinking and other human uses. Since the 1960s, major funding has been provided by local, state, and federal agencies to install centralized water systems in these villages. These systems have arrived with great expectations, and yet many of them have a myriad of problems due to harsh weather conditions, low winter temperatures, and permafrost. Other obstacles to success of the water systems arise from local preference for traditional water resources. On the Seward Peninsula, some villages rely heavily on centralized water systems, while others continue to rely more heavily on traditional water sources. We demonstrate in this paper that local variables, including different environmental factors and a sense of agency in the modernization process, affect local choices about whether or not to use the centralized water systems. We conclude that local, culturally specific ideas about health and acceptable drinking water quality must be taken into account for these projects to be successful.
\end{abstract}

Key words: freshwater, centralized water systems, water technology, Alaska, Iñupiaq, localization, technoscape, globalization, adaptation

RÉSUMÉ. Ces cent dernières années, la façon dont les villages iñupiaqs, en Alaska, se sont procuré l'eau douce nécessaire à la consommation et à d'autres usages humains a changé considérablement. Depuis les années 1960, des organismes fédéraux, locaux et d'État ont consacré beaucoup de financement à l'installation de réseaux centralisés d'alimentation en eau dans ces villages. Bien que les attentes étaient grandes à l'égard de ces réseaux, grand nombre d'entre eux ont connu une myriade de problèmes attribuables aux conditions climatiques difficiles de l'hiver, aux basses températures hivernales et au pergélisol. Parmi les autres obstacles à l'implantation réussie des réseaux d'alimentation en eau, notons la préférence qu'ont les gens de la région pour les sources d'eau traditionnelles. Dans la péninsule de Seward, certains villages dépendent fortement de réseaux centralisés d'alimentation en eau, tandis que d'autres villages continuent de dépendre surtout de sources d'eau traditionnelles. Nous démontrons dans cette communication que les variables locales, ce qui comprend divers facteurs environnementaux et la présence d'organismes se vouant au processus de modernisation, ont des incidences sur les choix faits dans la région, à savoir si les peuples décident de recourir aux réseaux centralisés d'alimentation en eau ou non. Nous en concluons que pour que ces projets réussissent, il faut tenir compte des idées des gens de la région en matière de culture, plus précisément en ce qui a trait à la santé et à une qualité acceptable d'eau potable.

Mots clés : eau douce, réseaux centralisés d'alimentation en eau, technologie de l'eau, Alaska, Iñupiaq, localisation, technopaysage, mondialisation, adaptation

Traduit pour la revue Arctic par Nicole Giguère.

\section{INTRODUCTION}

Access to a secure source of freshwater for drinking and other purposes is a basic human need. The present research is part of a larger study of freshwater regimes on the Seward Peninsula, Alaska, and their vulnerability to climate change. The project involved 12 researchers from the fields of anthropology, hydrology, engineering, and biology, whose goal was to integrate their varied expertise in a unified research approach. In the last 30-40 years, state and federal funding, along with engineering expertise, has allowed for construction of numerous small, centralized water systems in rural Alaska. Thus, one goal of the anthropology team and others was to understand how the relationship between villages and their source of drinking water evolves as new technologies are introduced.

Fieldwork sites were primarily small, Iñupiaq villages (180 to 615 people) situated along or near the western coast of Alaska, such as Elim, Golovin, Shishmaref, Wales, and White Mountain. No roads connect these villages to the outside world; they can be reached only by air, boat, or snow machine.

\footnotetext{
${ }^{1}$ Corresponding author: Department of Anthropology, University of Alaska Fairbanks, 905 NE 9th Street, Bend, Oregon 97701, USA; eliza132@yahoo.com

${ }^{2}$ Institute of Northern Engineering, University of Alaska Fairbanks, PO Box 755900, Fairbanks, Alaska 99775, USA

${ }^{3}$ Department of Anthropology, University of Alaska Fairbanks, PO Box 757720, Fairbanks, Alaska 99775, USA

(C) The Arctic Institute of North America
} 
While conducting fieldwork, researchers were surprised by the difference that existed between the villages of White Mountain and Shishmaref in the use of state-installed centralized water systems, given their similar locations, cultural affiliation, subsistence practices, and traditional language, as well as the striking consensus on this issue within each village. In White Mountain, all but four (of about 66) households use the centralized water system, which includes pumping water into the majority of peoples' homes, as the primary source of drinking water. In Shishmaref, despite the centralized water system in place on the island, the vast majority of people consider this water to be substandard. Local residents, even those who have running water piped into their homes, continue to procure drinking water by traditional methods, which include collecting rain and snow and hauling ice from tundra ponds. We chose to focus on these two villages instead of others because their internal uniformity made comparison viable.

These two similar villages with definitively different responses to the installed central water supply provide a unique opportunity, with respect to previous diffusion-ofinnovation studies (Rogers, 2004; Henrich, 2001, 2002) or studies that examine technology's influence on social change (Pelto, 1973; Gell, 1986; Bernard and Pelto, 1987; Arnold, 1995; Dobres, 2000; Best and Kellner, 2001; Krug, 2005), to examine how local social and environmental distinctions affect the acceptance of new technology. Our study contributes to the literature on social change, knowledge, technology, and information in a globalizing world (Pelto and Müller-Wille, 1987; Hume, 1988; Pfaffenberger, 1992; Krupnik and Vakhtin, 2000).

\section{METHODS}

In this paper, we explore the sources of drinking water used by people in the villages of Shishmaref and White Mountain, both now and in the past. We also discuss the installation and improvements of the centralized water systems over the last 30 years, and the difficulties that have arisen with these systems. Ultimately we argue that the decision to use treated water as a primary source of drinking water is connected to many different variables, including claiming agency during the process of modernization and local ideas of what is considered acceptable, healthy drinking water. Drawing on Appadurai's (1996:17) idea that globalization is essentially a localizing process, we examine how local variables have far-reaching effects on the decision to use (or not to use) the new, centralized water systems as the primary source of drinking water.

We refer to the villages as though they were single entities making choices, although clearly there are individual actors in both villages and many differences of perspective. We acknowledge that the choice to adopt a new, centralized water system is not easy and is often accompanied by feelings of nostalgia or a sense of loss competing with ideas of progress, tradition, and convenience and concepts of health.
In choosing between any two resources (i.e., a traditional water source vs. a centralized water system), some value is gained, and some is lost. We found the centralized water systems to be simultaneously welcome and problematic in both villages.

Fieldwork took place over three springs and summers (2003 to 2006). We gathered data through a mixture of semi-structured interviews and participant observation. In all cases, the anthropologists traveled, lived, and participated in summer and spring activities in the villages in order to contextualize the information from interviews. Interviews were conducted with a wide range of adults including both men and women. In each village over 20 people were interviewed formally and many others were part of the study during participant observations.

We use the term "traditional water source" to designate the ponds, rivers, snow, and rainwater used for drinking water, while the term "centralized water system" refers to central water treating systems that have been installed with government funds. "Raw water" is the pre-treated water used as input to the centralized water systems, and "treated water" is the output of the centralized water system. Our information about traditional ways of procuring freshwater comes mostly from the explanations given by elders in the villages.

\section{CASE STUDIES: WHITE MOUNTAIN AND SHISHMAREF}

The Seward Peninsula on the west coast of Alaska is the closest U.S. non-island landmass to Russia. Figure 1 shows the location of White Mountain and Shishmaref, the two villages where research was conducted, and Nome (pop. 3000), the economic and marketplace hub for both villages. White Mountain, located on the Fish River, is considered an inland community when compared to most other Iñupiaq villages. It has a population of 244 people, of whom $86.6 \%$ are Alaska natives according to the 2005 census (ADCCED, 2004a). The native population in White Mountain is both Yupik and Iñupiaq, though Inupiaq is the traditional language group and continues to be the predominantly claimed cultural affiliation (Marino, 2005). Most people in White Mountain today consider themselves to be descendents of the Igaluigmiut or Fish River tribe, a linguistic and cultural sub-group of the Iñupiaq people.

Shishmaref is located on Sarichef Island (Kigiqtaq), a barrier reef island that is surrounded by the Chukchi Sea to the north and Shishmaref Inlet to the south. Shishmaref's population of 615 is predominantly of Iñupiaq heritage. Most residents refer to themselves as descendents of the Tapqagmiut (people along the sandy shore).

\section{CHANGING WAYS OF FETCHING WATER}

While ethnographers and anthropologists working in the Arctic have long documented the relationship between 


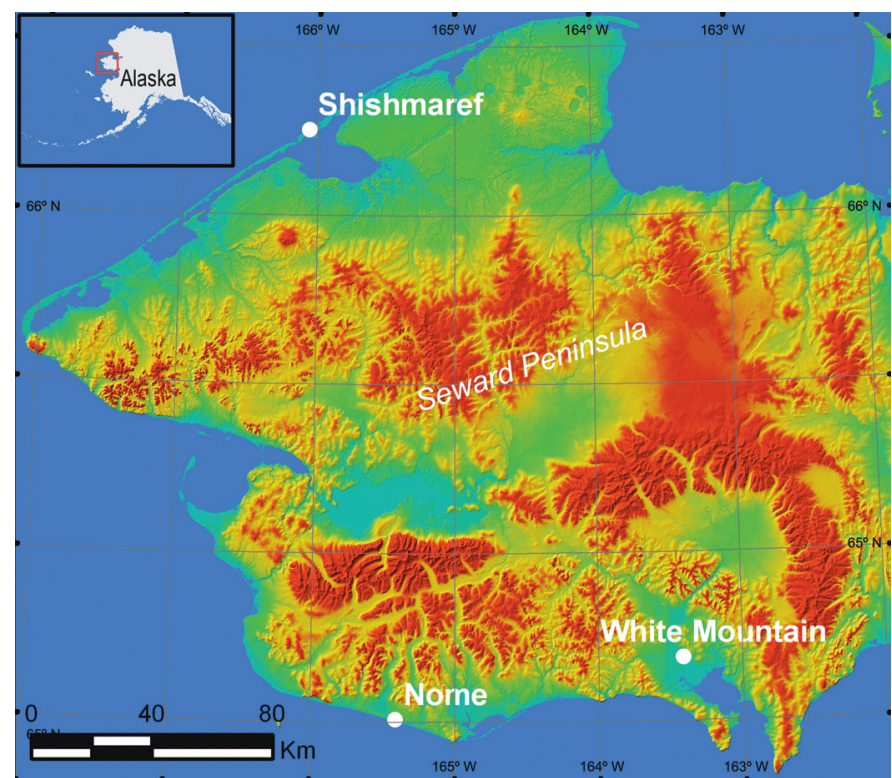

FIG. 1. Map of the Seward Peninsula on the western coast of Alaska, showing the locations of the hub city of Nome and the main villages visited and researched for this article.

Arctic peoples and the sea, nearly no research exists on the relationship between Arctic peoples and freshwater. An exception is the recent work in Nunavik, Canada, of Martin et al. (2007).

Before the gold rush on the Seward Peninsula-which took place near the turn of the last century and brought with it a dramatic influx of non-Iñupiaq people (Grauman, 1977) - Iñupiaq people hauled water from traditional sources in containers made from the stomach linings of walrus and seals or the hides of sea mammals, similar to a seal poke (J.J., pers. comm. 2005). Water was gathered from rivers, melting clean sea ice, rain, and underground springs, the latter being considered the most favorable (B.B., pers. comm. 2007). After the gold rush came an influx of Western goods and new types of containers to hold those goods. The Iñupiaq people are said to have used these empty containers for a variety of purposes. Many people testify that five- and tengallon Coleman fuel cans were quickly adapted into water yokes and used to haul water to homes. These cans were eventually replaced by plastic buckets. Bathing tubs were adopted over time, and bath water was heated on a stove to fill the tub. One woman in White Mountain estimated the level of water usage at mid-century to be about 13-14 gallons per person each week, most of it hauled from the river.

Every Saturday I filled a 55-gallon drum, which was used throughout the week by four people. Holes were made in the ice during the winter. They were opened with a tuuk, sharp stone or metal used on the end of a wooden stick, before augers.

(R., pers. comm. 2004)

Methods of water procurement continued to include collecting rain and snow and taking clean ice from the top of ocean ice, as well as hauling water from traditional sources (R., pers. comm. 2005).

Throughout most of the 20th century, Iñupiaq and Yupik populations on the Seward Peninsula remained seminomadic and often spent at least the summer at fish camps (Ray, 1975, 1983). This lifestyle meant that traditional water resources were associated with seasonality: no single source location was exploited all year long, nor was human waste deposited in one location. This arrangement in regard to water resources was both sanitary and sustainable (Berardi, 1999). Today around White Mountain, nearly all fish camps have a fresh spring nearby that the family can use when the river is either too muddy or contaminated by dead and dying salmon, a period of time during the fall known as mulukchuk.

While in earlier days the drive to sanitize often went hand in hand with the goals of outsiders to missionize and educate Native Alaskans (Berardi, 1999), in the 1960s state and federal agencies became particularly concerned with how rural Alaskan villages secured water safe for drinking and disposed of human waste. Over the next 43 years, interest in providing safe water for rural Alaskan villages became an expensive and expansive undertaking that continues to the present. Between 1960 and 1970, the Indian Health Service undertook several centralized water projects to insure safe drinking water sources for villages, but it wasn't until 1972 that construction of small, centralized water systems began in Alaska in earnest. Between 1972 and1994, major funding from the state became available and the Village Safe Water Program became an institution. Nearly $\$ 300$ million of state support went to sanitation projects during those years. In 1994, the U.S. Department of Agriculture and the Environmental Protection Agency began to provide funding for the program. By 2005, $\$ 537$ million of combined federal funds and \$240 million from the State of Alaska had been invested in the program (ADEC, 2008).

The Village Safe Water (VSW) program is the institution that handles the process of turning this money into centralized water systems for rural Alaska. Villages themselves apply for grant money from the VSW program. The applications are then ranked on whether the project will "address critical public health needs as well as the communities' demonstrated capacity to operate and maintain the facilities" (ADEC, 2008). Available grant money is given out to the highest-ranking applicants until funds are exhausted.

\section{CURRENT WATER SYSTEMS}

Both Shishmaref and White Mountain have received centralized water systems through the VSW Program. In 1974, Shishmaref received a water treatment plant and water access point that required residents to self-haul water to their home or point of use. In 1976, 70 households were put on haul service, meaning that water was hauled to the homes by a centrally managed delivery service. Today, construction of a flush/haul system is in progress. 


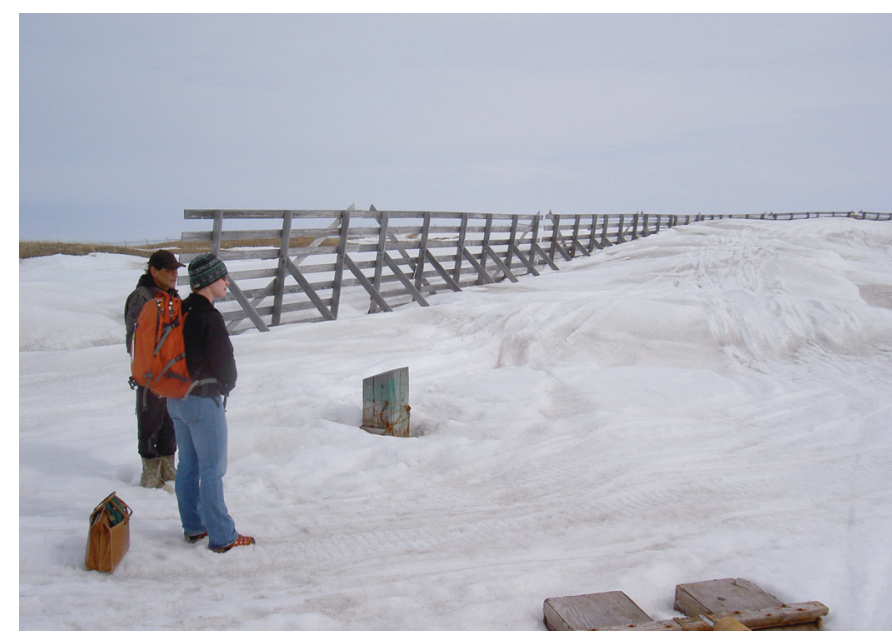

FIG. 2. The lined water catchment of Shishmaref, Alaska, surrounded by a fence. An engineering graduate student and a Shishmaref resident are surveying the outer area of the community's potential water supply.

Shishmaref's central water system is operated by the municipal government. The water system consists of raw water collection, water treatment, a washeteria, a central watering point, and water delivery by vehicle. The washeteria, an important central location in many villages, is the building that houses the water treatment plant, as well as public showers, toilets, and washing machines. Raw water to supply the system comes from a surface water source and is filtered and chlorinated (ADCCED, 2004b). Shishmaref's surface source is a lined catchment area, on one side of which snow fences were built to enhance snow catch (Fig. 2). Snowmelt is then retained at the surface for use. Treated water is stored in a 300000 gallon tank. A project in progress is installing household plumbing and a flush/ haul system. Those households with tanks installed can have water delivered, and others can haul water from the watering point at the washeteria. Waste is deposited in sewage lagoons via sewer pipes (several public buildings), honey bucket haul, or flush tank haul.

In White Mountain, a well was drilled as early as 1964, followed by another well in 1968. By 1986, a piped water delivery system was installed, and upgrades have occurred continuously since then. The well currently in use was drilled in 1968 and is 129 feet deep. Information provided by community members in 2004 indicates that the original well, drilled in 1964 to a depth of 118 feet, was contaminated with oil. The newer well, 400 feet up a hill from the original 1964 well location, is pumped continuously at 24 gallons per minute to meet demand and keep a 150000-gallon storage tank full. Major upgrades were made around 1981, including a new water plant and tank, with pipes following within a few years (Fig. 3). When the 1981 water plant was installed, the design population was 250 people, with a per capita use of 15 gallons per day. The distribution system has one loop serving the town, and continuous pumping prevents freezing. The water system and washeteria are operated by the municipal government. Water is filtered, chlorinated, and fluoridated (ADCCED, 2004a; authors' field notes). Piped

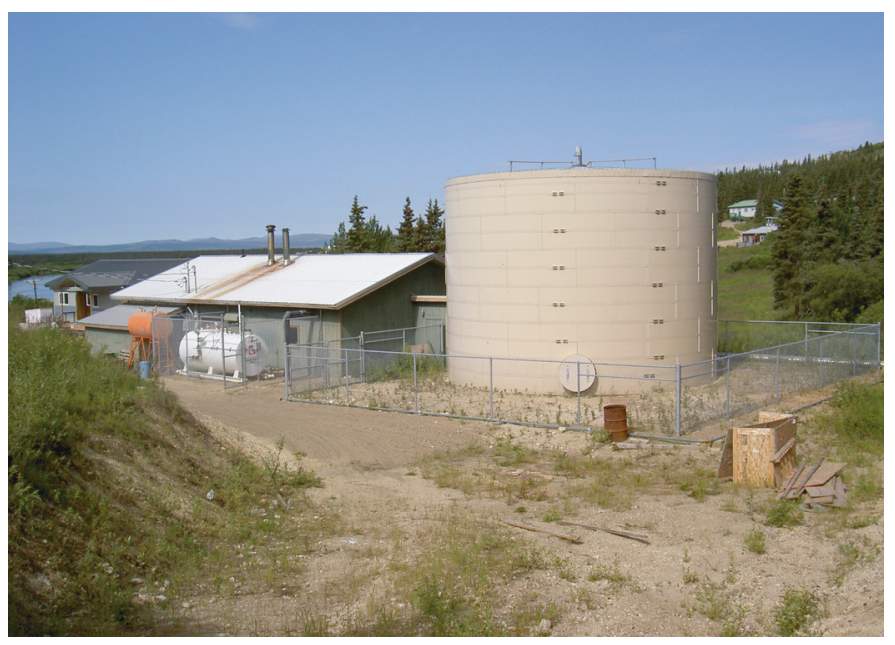

FIG. 3. Water tank in White Mountain, Alaska.

sewage has recently been installed in White Mountain to convey sewage to an open lagoon for treatment.

\section{OBSTACLES TO THE NEW WATER SYSTEMS}

\section{Engineering}

While these new water systems were welcome additions to Arctic village life, in most cases problems existed from their inception, due in part to the sheer engineering feat involved in designing small systems that could withstand the cold, remote locations. The Arctic environment poses a particular challenge to centralized drinking water systems. Conventional deep burial water distribution mains are not practical in the Arctic because of permafrost, so water mains are most often laid on top of the ground, exposed to harsh winter temperatures. These water lines can be insulated and heated to prevent freezing, but only at exceptional cost. In an environment where power is intermittent, freezing failure is inevitable, and often is the cause of ultimate system failure. In some cases, water mains have been buried in permafrost that has been trenched with rock saws. While these systems still must be protected from freezing, the more important challenge is protecting the permafrost from the heat of the pipe. More often than not, the heat from the pipes has thawed the permafrost, resulting in trench failure and system collapse. In some areas where permafrost is discontinuous or thawing, burial of water mains has been successful. Even buried, the water must be protected from freezing, as cold winters drive frost eight to ten feet below the surface.

The Arctic is an arid or semi-arid landscape. Despite the wetlands that abound on the coastal plains, little more rain falls there than in the desert Southwest of the United States. Surface water is abundant only when it is perched at the surface atop permafrost. Central water systems require a sufficient supply of water to distribute to all users. Collecting a sufficient amount of water from this thin layer of wetlands is 
difficult. In many cases, Arctic communities identify shallow tundra ponds that ultimately serve as the central water reserve. Since most of these ponds freeze to the bottom in winter, communities must collect, treat, and then store the water in heated tanks to last the winter. Whereas municipalities outside the Arctic generally reserve little more than 100 gallons per person in storage, Arctic communities must store tens of thousands of gallons of water per person to last the long winter months when the municipal water reserve is frozen. Heating large volumes of water can be extremely expensive where diesel fuel costs more than $\$ 5$ per gallon. In some areas of the Arctic, where the ground is thawed or thawing, wells have been drilled. Groundwater wells can serve as an abundant source of clean drinking water. In areas of continuous permafrost, however, groundwater is very deep and may not be accessible to small communities (Ryan, 1990).

Engineers who design these systems are faced with complex federal regulations, as well as all the challenges posed by the Arctic environment. As a result, more often than not, engineers have designed systems that are too complicated or too expensive for a community to maintain.

\section{Costs and Maintenance}

Operating and maintaining a centralized water system in the Arctic has also proven problematic, particularly in communities that continue to live a subsistence lifestyle with a limited cash economy. Centralized water systems require continuous attention to prevent freezing and maintain public health. When communities relied on traditional water sources, drinking water was decentralized and the potential risk to the population by a contaminated drinking water source was small. If a centralized water system becomes contaminated, the entire population is at risk. Since Arctic communities generate limited funds, often they cannot pay for even minor repairs. Many central water systems in the Arctic have failed because of a missing fuse, pump, or heater. Although communities levy a monthly fee to pay for centralized water, residents may not have the money to pay the fees required.

Compounding operations and maintenance problems in the Arctic is the lack of economies of scale. In a city with thousands of water connections, the non-payment by a dozen residents has no impact on the water service function. In a small community with only 40 service connections, nonpayment by a dozen residents may result in lack of maintenance and system failure. Centralized water systems cannot "rest" un-maintained. Once frozen, tanks, pipes, and pumps crack and become unusable.

When new centralized water systems are constructed in the Arctic, or when major repairs are needed, community remoteness cannot be overlooked. It may take weeks to have parts shipped to sites and major components (e.g., pipes) may take months. Expert personnel often must be flown to the community to program system computers or address system performance issues. When these experts leave the community, no local knowledge remains to fix the problems that inevitably recur.

\section{Taste and Health}

Other obstacles to the success of these systems have had to do with personal preference. During fieldwork in the villages of Shishmaref and White Mountain, we found that local community members overwhelmingly preferred the taste of water from traditional sources to centralized, treated water. Most people also believed that drinking water from traditional sources was superior in terms of health and safety. In White Mountain, respondents in 16 of the 21 households interviewed said they preferred the taste of river water and found it to be "better for you." Three had no opinion, and only two felt that the treated, piped water was safer to drink.

In interviews and in casual conversations, the conviction that drinking water from traditional sources brought health benefits was clear. The following comments came from semi-formal interviews with local residents during the summer of 2005. Residents were asked to identify their preferred source of drinking water, their most commonly used source of drinking water, and the perceived quality of both traditional water sources and the centralized water system. The following are examples of typical responses.

River water is better. We have a clean and well taken care of river.

(H.L., pers. comm. 2005)

I believe it [traditional water source] is better because the tap water has a lot of chemicals.

(C.N., pers. comm. 2005)

River water is better for you in the long run.

$$
\text { (P.A., pers. comm. 2005) }
$$

It has a distinctive sweet taste. You can't get enough of it.

(S.S., pers. comm. 2005).

Over and over in interviews and in conversation, people in White Mountain pointed out that the tap water was full of lime (a consequence of the rock formation around the local well) and chemicals, while river water tasted better and was "more natural" (S.L., pers. comm. 2005). In Shishmaref, one young woman reported that it was "disrespectful" to serve coffee or kool-aid made with treated water to elders (S.P., pers. comm. 2004). The idea that treated water "tastes like chemicals" and is "bad for you" became a common theme in discussions about treated water.

It should be pointed out that upgraded, centralized water systems are desired, and villages work hard towards the acquisition of modern facilities. There are many local reasons to desire modernized water systems, such as flush toilets, showers, washing machines, etc. However, water taken 
from traditional sources is considered highly superior in quality for drinking water.

\section{USING CENTRALIZED WATER SYSTEMS}

Both White Mountain and Shishmaref experienced the problems of installing a small water system in their village. Both villages have had past difficulty with contamination. Both villages are currently on the list of significant non-compliers as of December 16, 2006 (Dept. of Environmental Conservation, 2008). In both White Mountain and Shishmaref, the majority of people interviewed feel that traditional water is superior in taste and health benefits.

Despite experiencing similar problems, White Mountain residents consistently use the centralized water system as their primary source of drinking water, while Shishmaref residents do not. Anecdotally, this became clear to anthropologists after spending time in the respective villages. Water-use estimates constructed through centralized water system measurements confirm anecdotal experience in the field (Fig. 4).

White Mountain uses far more water from the public water system, both as a community and per capita, than Shishmaref does. In White Mountain, population 244 (2005), the city pipes around 10000 to 15000 gallons per day to homes, along with an additional 2000 to 5000 gallons for daily use at the washeteria. During the summer, residents water gardens and in the winter, some toilets have to flush automatically to prevent freezing, using approximately 25000 gallons per month. In Shishmaref, population 615, water use barely reaches 5000 gallons per month (Fig. 4).

Out of the 21 households surveyed in White Mountain in 2005, only three continued to use the river (traditional source) as their main source of drinking water. The cost of water piped into the homes in White Mountain is $\$ 60$ per month for unlimited, un-metered water use. The majority of people interviewed believed this amount to be reasonable and not financially burdensome.

White Mountain is located on the Fish River, and households without piped water can access the river as a source of water. In the winter, when the river freezes, a hole is kept open with an ice auger so that residents of White Mountain have access to river water throughout the year. In spite of the preference for the taste of water from traditional sources, people continue to consume water from their tap. The most common answer for why people used treated water is that "it's just more convenient."

In Shishmaref, while treated water is used for washing clothes and bathing, drinking water continues to be taken predominantly from traditional water sources. Treated water from the centralized water system in Shishmaref is locally considered substandard and is rarely used as a source of drinking water. In different seasons, different methods of water procurement are used. During early spring and summer, families can purchase two plastic water cans full of water or snow. After the first rains of spring have cleaned

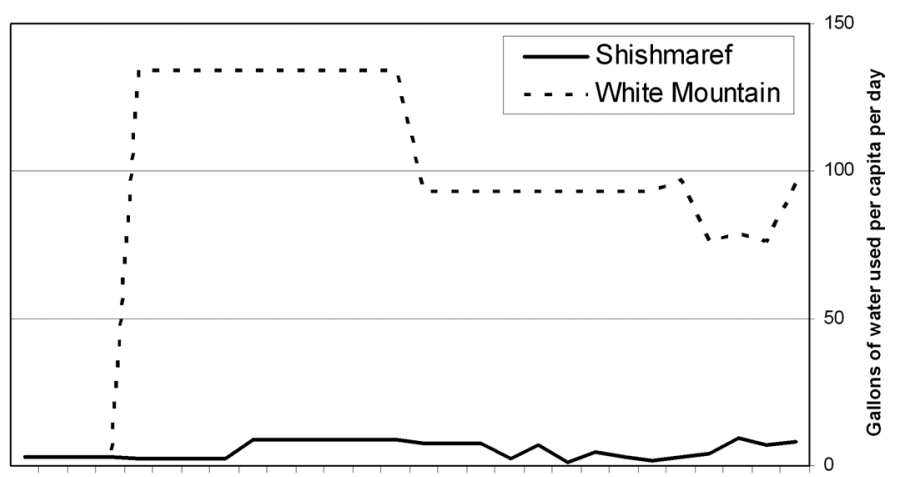

19771979198119831985198719891991199319951997199920012003 Year

FIG. 4. Water use levels (gallons per day) in the villages of Shishmaref and White Mountain, Alaska, during the 20th century. Data extracted from centralized water system records collected by the authors were used in preparing the graphs.

stove-oil soot off the roofs of homes, rainwater is collected individually. By mid-June, when frozen lagoon and river ice has broken up, hunters and families collect freshwater from streams. During spring hunting for bearded seals and walrus, water is taken from meltwater puddles on floating sea ice. During winter, when snow and ice accumulation allow for safe snowmobile travel, water is taken from rivers located on the mainland, approximately five to eight miles away from the village. The river ice is broken up into pieces and hauled back to the village on a sled. Cost runs around $\$ 50$ per sled load. This ice is then stored in plastic containers inside of homes until it melts. After melting, the water is used for drinking and cooking.

In both villages, the decision to continue to exploit traditional water sources or to use the installed centralized water system is generally uniform.

\section{THE LOCATION OF NEW TECHNOLOGY}

In White Mountain, the majority of households have water piped to their homes, which means the water runs into sinks and bathrooms as in most American homes. In Shishmaref, the majority of households do not. This basic difference could explain some of the water use statistics given above. Interestingly, however, in Shishmaref, even households that do have "running" water continue to haul water for drinking from traditional sources.

In winter, hauling water from traditional sources can mean traveling up to eight miles for water from a frozen pond on the mainland or hiring someone (typically a young male hunter) to collect water. Travel to and from these ponds in the winter can take over an hour and a half. Despite this, one woman interviewed in Shishmaref felt that hauling water from traditional sources was more convenient than using water piped into the house. She explained that she and her husband had running water until the pipes froze four years ago. They chose not to fix the pipes. Now the couple is contemplating building a new home and when asked 
whether she would install running water in their new house, the woman answered, "Maybe not. It's just a hassle" (F.T., pers. comm. 2004).

The decision making that leads villages to use or not to use the centralized water systems, to think of them as convenience or hassle, is no doubt complex. The two villages differ in a number of ways. The histories of White Mountain and Shishmaref during the gold rush, for example, are distinct, as are some specific ceremonies, population, and more (Ray, 1983; Burch, 1988). We choose to focus on two local variables in each village that we hypothesize correlate with and help to explain the local decision to use or not to use the centralized water system.

\section{Environmental Differences}

As noted above, Shishmaref's raw water is taken from a surface source that is supplied by snow catchment. This area is shallow, and the fences erected to enhance snow catch are permeable. The water is treated and made potable, but the source itself-visible to the public - appears to many to be less than desirable. In other words, this source would not be considered acceptable drinking water to people who are accustomed to identifying healthy drinking water out on the land.

In White Mountain, the raw water source is an underground well. That good, healthy water comes from underground springs is well known to local residents. In fact, spring water is highly regarded, and the locations of the "best" springs up and down the river are well known among people in the village. The raw water source, therefore, fits into the conception of acceptable water already identified by local residents. Thus, in White Mountain, there is continuity between the concept of drinking water from traditional water sources and that of using contemporary sources. In Shishmaref, there is no such correlation, and a complete reconceptualization of what is considered acceptable drinking water is necessary.

\section{Agency in Modernization}

There was another striking feature in interviews with people from White Mountain that was missing from interviews in Shishmaref. In White Mountain, there was a clear pride in the centralized water system as such. Diplomas for the water plant operator's education hung from the walls of the city offices. Many people commented that it was the intelligence of local grant writers - now pillars of the community - who applied early for the installation of the water system and later for monies for improvements to that water system. People say this foresight allowed White Mountain to modernize early and rapidly. One resident commented, "White Mountain's water system is the best on the Seward Peninsula" (E.T., pers. comm. 2005). Another woman said, "it's a lot better than most villages" (B.B., pers. comm. 2005).

In White Mountain, the centralized water system and its installation, success, and subsequent upgrades are conceptualized as having been brought into the village by the village itself. The modernization process therefore is locally driven and agency is retained. In effect, the new technology has become "our" new technology.

How this sense of agency in the modernization process emerges is more difficult to understand. What we can say is that during interviews, many residents of White Mountain linked the quality of the water system and its success to the decisions made by individual actors, who were respected men and women in the village. These individual actors and the decisions they make have far-reaching effects in localizing new technology.

\section{DISCUSSION AND CONCLUSION}

To understand the history of the centralized water systems in Shishmaref and White Mountain and the evolving ways of procuring drinking water in those two villages, we looked at the obstacles for engineers in trying to develop practical, centralized water systems for small, rural communities in the Arctic. We were also interested in local ideas about what was and is considered healthful, safe drinking water both in the past and at present. We found that while there are clearly many benefits to having a centralized water source, there are also a number of difficulties in maintenance and cost, as well as a local preference for the taste and health benefits of traditional water sources. When a local population decides to use or not to use the centralized water system, all of these factors come into effect.

Between these two villages, the source water for the centralized water systems differed dramatically. Also different was the sense of local agency in the success of the centralized water systems. We hypothesize that these two small, local variables play a central role in understanding local decision making. There is much work left to be done in understanding how local variables and perceptions affect the decision to use centralized water systems. Also unknown is the reverse: how centralized water systems affect people's perceptions of drinking water. This research would be valuable not only in the Arctic, but all over the world as new water technology is rapidly being introduced.

During the processes of globalization, shifts in what Appadurai (1986, 1996) has called the "technoscape" are inevitable. By this we mean both that new technologies are introduced and that perceptions of those new technologies are constantly shifting. Anthropologists have shown that often new technologies fail to be effective when local perception is not taken into account (Dewalt, 1975). While the Village Safe Water program and the State of Alaska have done much to take local perception seriously, perhaps there is still more to be done.

Martin et al. (2007) examined the use of traditional water sources among Inuit residents in Nunavik, Canada, and concluded that further education of local residents was needed in order to raise awareness of the potential health risks associated with using traditional water sources for drinking 
water. We agree with this suggestion. We further suggest that policy makers, engineers, maintenance crews, and other non-local people who work in indigenous communities in the Arctic also be educated to obtain a more nuanced understanding of local perceptions and ideas, such as what is locally considered healthy water and why.

Installing centralized water systems in rural Alaska has been a major project of the state, financially, socially, and intellectually. With the changes in climate and recorded warming that are currently occurring in much of the Arctic, there may be increased pressure on water systems that support human life (Martin et al., 2007). While continuing the larger project of providing basic needs to Arctic residents, we note that the success of these large government projects is always and inevitably dependent on local perception and participation.

\section{ACKNOWLEDGEMENTS}

The Intersection between Climate Change, Water Resources and Humans in the Arctic (ICWHA) research project has been supported by the U.S. National Science Foundation under the Arctic System Science Program (OPP-0328686). The project was under the direction of Daniel M. White, Larry D. Hinzman, Lilian Alessa, and Peter P. Schweitzer. Additional thanks go to freshwater colleagues Andy Kliskey, Bob Busey, Erin Strang, Jack Omelak, and Paula Williams. This research could not have been carried out without the generous support from the communities in Shishmaref and White Mountain, Alaska, particularly the patient help of knowledgeable elders in those communities. Any errors or opinions put forth in this paper are, as always, the authors' own.

\section{REFERENCES}

ADCCED (Alaska Department of Commerce, Community, and Economic Development). 2004a. White Mountain. In: Alaska community database: Community information summaries. http://www.commerce.state.ak.us/dca/commdb/CIS.cfm.

- 2004b. Shishmaref. In: Alaska community database: Community information summaries. http://www.commerce. state.ak.us/dca/commdb/CIS.cfm.

ADEC (Alaska Department of Environmental Conservation). Village Safe Water program description. http://www.dec.state. ak.us/water/vsw/.

Appadurai, A. 1986. Introduction: Commodities and the politics of value. In: Appadurai, A., ed. The social life of things. Cambridge: Cambridge University Press. 3-63.

- 1996. Modernity at large: Cultural dimensions of globalization. Minneapolis: University of Minnesota Press.

Arnold, J.E. 1995. Transportation innovation and social complexity among maritime hunter-gatherer societies. American Anthropologist 97:733-747.

Berardi, G. 1999. Schools, settlement, and sanitation in Alaska Native villages. Ethnohistory 46(2):329-359.
Bernard, R., and Pelto, P. 1987. Technology and social change. Prospect Heights, Illinois: Waveland Press.

Best, S., and Kellner, D. 2001. The postmodern adventure: Science, technology, and cultural studies at the third millennium. New York: The Guilford Press.

Burch, E.S., Jr. 1988. The Iñupiaq Eskimo nations of Northwest Alaska. Fairbanks: University of Alaska Press.

DeWalt, B.R. 1975. Inequalities in wealth, adoption of technology, and production in a Mexican ejido. American Ethnologist 2(1):149-168.

Dobres, M.-A. 2000. Technology and social agency: Outlining a practice framework for archaeology. Oxford: Blackwell Publishers.

Gell, A. 1986. Newcomers to the world of goods: Consumption among the Murai Gonds. In: Appadurai, A., ed. The social life of things. Cambridge: Cambridge University Press. 110-138.

Grauman, M.W. 1977. A historical overview of the Seward Peninsula-Kotzebue Sound Area. National Park Service: Department of the Interior.

Henrich, J. 2001. Cultural transmission and the diffusion of innovations. American Anthropologist 103:992-1013.

- 2002. Decision-making, cultural transmission and adaptation in economic anthropology. In: Ensminger, J., ed. Economic anthropology: Theory at the turn of the century. New York: Rowman and Littlefield Press.

Hume, S. 1988. A North that can be felt but never known. In: Wonders, W.C., ed. Knowing the North: Reflections on tradition, technology and science. Occasional Publication 21. Edmonton: Boreal Institute for Northern Studies. 95-105.

Krug, G. 2005. Communication, technology and cultural change. London: Sage Publications.

Krupnik, I., and Vakhtin, N. 2000. Indigenous knowledge in modern culture: Siberian Yupik ecological legacy in transition. Arctic Anthropology 34:236-252.

Marino, E.K. 2005. Negotiating the languages of landscape: Place naming and language shift in an Iñupiaq community. MA thesis, Department of Anthropology, University of Alaska Fairbanks.

Martin, D., Bélanger, D., Gosselin, P., Brazeau, J., Furgal, C., and Déry, S. 2007. Drinking water and potential threats to human health in Nunavik: Adaptation strategies under climate change conditions. Arctic 60(2):195-202.

Pelto, P.J. 1973. The snowmobile revolution. Prospect Heights, Illinois: Waveland Press.

Pelto, P.J., and Müller-Wille, L. 1987. Technology and anthropological theory. In: Bernard, R.H., and Pelto, P.J., eds. Technology and social change. Prospect Heights, Illinois: Waveland Press, Inc. 359-377.

Pfaffenberger, B. 1992. Social anthropology of technology. Annual Review of Anthropology 21:491-516.

Ray, D.J. 1975. The Eskimos of Bering Strait 1650-1898. Seattle: University of Washington Press.

1983. Ethnohistory in the Arctic: The Bering Strait Eskimo. Kingston, Ontario: The Limestone Press.

Rogers, E.M. 2004. A prospective and retrospective look at the diffusion model. Journal of Health Communication 9:13-19.

Ryan, W.L. 1990. Surface water supplies: Cold regions and hydraulics. New York: American Society of Civil Engineers. $301-316$. 